\title{
AS TRAPAÇAS DE UM SOFISTA ou da aprendizagem da insubmissão em Lavoura arcaica, de Raduan Nassart
}

Luciana Wrege Rassier

Foi durante a ditadura militar que o paulista Raduan Nassar publicou:

- Lavoura arcaica (1975): um romance frequentemente descrito como uma versão da parábola do filho pródigo, que põe em cena uma família patriarcal e rural, organizada em torno de valores austeros baseados no trabalho e na disciplina. Esse romance narra o retorno do personagem-narrador à fazenda, de onde fugira após haver consumado o incesto com sua irmã.

- Um copo de cólera (1978): uma novela que conta a noite de amor de um casal e sua violenta briga no dia seguinte.

Apesar da acolhida entusiasta de sua obra pela crítica, Raduan Nassar declarou em 1984, para a surpresa de todos, que abandonaria a literatura para dedicar-se à sua fazenda (Massi e Sabino, 1984). Portanto, há mais de vinte anos, ele mantém uma relação ambígua com o universo literário, pois, se por um lado, afirma que não lhe interessa mais, por outro, ele faz-se presente na cena literária, como confirmam vários fatos:

- em 1996, o primeiro número dos Cadernos de Literatura Brasileira do Instituto Moreira Salles sobre um romancista é consagrado a Nassar, que contribui propondo um texto inédito e respondendo a uma longa entrevista - que ele revisará por escrito antes da publicação, como costuma fazer; 
- em 1997, publica uma coletânea de textos curtos, Menina a caminho, enquanto seus dois livros precedentes são reeditados pela Companhia das Letras;

- participa do Salão do Livro de Paris, em 1998, como membro da comitiva brasileira oficial;

- Um copo de cólera e Lavoura arcaica são adaptados para o cinema (respectivamente, em 1999 e 2001).

No entanto, ainda há poucos estudos mais aprofundados sobre a obra de Raduan Nassar, o que decorre provavelmente da complexidade de sua escrita, como sublinhava Leyla Perrone-Moisés, já em 1977, sobre Lavoura arcaica:

Este primeiro romance do jornalista Raduan Nassar alcançou logo um êxito de estima, entre os intelectuais, sem ter, entretanto, uma larga repercussão pública e sem suscitar uma análise crítica desenvolvida. Compreende-se que isso tenha acontecido. A linguagem deste romance é de molde a inibir qualquer metalinguagem. É um discurso tão denso, tão desmesurado em seu lirismo, tão inusitado em suas ressonâncias bíblicas e islâmicas, que um comentário a ele aposto corre logo o risco de leviandade e de insignificância. (Perrone-Moisés, 1977, p. 96)

No presente artigo propomo-nos a elucidar como, em Lavoura arcaica, mecanismos textuais baseados na prática da retórica remetem ao questionamento da autoridade e da presumida "verdade" que ela tenta impor através de seu discurso hegemônico ${ }^{2}$. Para tanto, estudaremos num primeiro momento como Raduan Nassar vê os sofistas e sua arte do discurso. Num segundo momento, passaremos à análise das práticas retóricas de três personagens de Lavoura arcaica, a saber, o patriarca, seu primogênito, e o personagem-narrrador.

\section{Os sofistas, "trapaceiros da Antiguidade"}

Sabemos que desde seu início a sofística diz respeito à relação entre linguagem e poder, pois, quando ela surgiu na Sicília, cinco séculos antes de Cristo, a democracia sucedia à expulsão dos tiranos que haviam governado e o poder era conquistado por aqueles que dominavam a linguagem e a argumentaçáo - notadamente quando dos processos que designavam os novos proprietários das terras confiscadas. Foi esse contexto que suscitou a apariçáo dos sofistas, professores ambulantes, pagos para ensinar as estratégias do discurso.

Convém ainda lembrarmos que a visão negativa que temos dos sofistas é reforçada pelo fato de que seus textos nos chegaram de modo fragmentado e parcial. Além 
disso, seus ensinamentos foram-nos transmitidos essencialmente por filósofos que os rejeitavam e sublinhavam a discrepância entre o discurso sofístico e uma pretensa verdade, como Platão ("o que traz o sofista é uma falsa aparência de ciência universal, mas não a realidade”, $O$ sofista, 233c) e Aristóteles ("a sofística é uma sabedoria aparente, sem a mínima realidade; o sofista é aquele que faz negócios utilizando essa sabedoria aparente e sem realidade", Réfutations sophistiques, I, 165 a 21 - tradução nossa).

Embora em geral Raduan Nassar seja circunspecto quando se trata de revelar suas referências literárias ou teóricas, na entrevista aos Cadernos de Literatura Brasileira do Instituto Moreira Salles, em 1996, ele afirma claramente seu interesse pelos sofistas ${ }^{3}$. É precisamente nessa imagem negativa que deles temos que Nassar insiste, apesar de fazêlo com um tom paródico, combatendo desse modo a crítica a esses mestres do discurso e invertendo o julgamento de valor que ela veicula. Ao mesmo tempo em que os designa como "aqueles trapaceiros da Antiguidade", Nassar atribui-lhes a funçáo de paradigma que estimulou sua reflexão própria ${ }^{4}$, principalmente sobre a versatilidade da razão e de seu suposto caráter ético 5 .

Nassar também explicita seu gosto pela prática da relativização obtida graças a manobras discursivas inspiradas pela sofística:

Quanto aos sofistas, meu entrosamento com eles tinha a ver com a minha própria prática. Numa discussão, por exemplo, não ia mais que o tempo de eu sacar qual era a do meu interlocutor para imediatamente defender a tese contrária. Me entreguei por muitos anos a esse jogo, e fazia isso com ardor, com paixão, e se por acaso meu interlocutor chegasse até a minha, eu imediatamente passava a defender sua tese original (Cadernos de Literatura Brasileira, 1996, p. 37).

Ora, tal estratégia corresponde a uma técnica recorrente nos escritos dos sofistas, a argumentação in utramque partem, ou seja, suscetível de ser explorada tanto para criticar quanto para defender uma mesma ideia. Nessa perspectiva, compreende-se melhor o sentido da declaração abaixo, feita por Nassar em resposta ao jornalista que parece haver identificado sua tática:

- Você fala coisas para se divertir com o efeito delas.

- Que compromisso existe? Você pode falar uma coisa e seu contrário. E daí? (Bonassa, 1995 - grifo nosso).

Mas constatar o interesse de Nassar, persona literaria, pela retórica não teria sentido se náo identificássemos a mesma tendência em seus textos de ficção. 


\section{Dos oradores nassarianos em Lavoura arcaica:}

\section{O pai e seu sermão sobre o tempo}

Quando nos interrogamos sobre as representaçóes do orador na obra nassariana, é a personagem do pai em Lavoura arcaica que se impóe. É, sobretudo, em seu sermão sobre o tempo (Nassar, 1997, p. 53-63) que tal personagem comporta-se como um orador hábil, demonstrando que domina as cinco qualidades exigidas na retórica clássica: a invenção, a disposição, a memória, o estilo e a ação oratória ${ }^{6}$.

Inicialmente, no que tange à invenção, o patriarca não apenas escolhe argumentos que colocam em cena o universo da família - o que ocasiona uma certa adesáo por parte de seus ouvintes - , como ainda utiliza exemplos que, além de auxiliar na compreeensão das ideias tratadas, reforçam a convicção sobre seu interesse, permitindo a indução e o raciocínio por analogia.

Quanto à disposição, esta personagem inicia seu exórdio por um aforismo com valor de verdade geral indiscutível ("O tempo é o maior tesouro de que um homem pode dispor" - Nassar, 1997, p. 53), cujo eco encontramos na fórmula que encerra a peroração: "a paciência é a virtude das virtudes, não é sábio quem se desespera, é insensato quem não se submete" (Nassar, 1997, p. 62) ${ }^{7}$. Com efeito, reconhecemos nessa definição da paciência o mesmo tom superlativo utilizado no começo do sermão - e tal escolha tem evidentemente o objetivo de persuadir os ouvintes da importância do assunto tratado:

O tempo é o maior tesouro de que um homem pode dispor; embora inconsumível, o tempo é o nosso melhor alimento; sem medida que o conheça, o tempo é contudo nosso bem de maior grandeza: não tem começo, não tem fim; é um pomo exótico que não pode ser repartido, podendo entretanto prover igualmente a todo mundo (Nassar, 1997, p. 53-54).

Num primeiro momento, o pai louva o tempo e o situa em uma esfera superior. Mas se faz isso é no intuito de incrementar a importância de seu discurso, que pretende ser a chave para alcançar este bem tão precioso. Com extrema habilidade, o tempo é a seguir aproximado do cotidiano da família: ao torná-lo acessível, o patriarca suscita o interesse dos que o escutam - "existe tempo nas cadeiras onde nos sentamos, nos outros móveis da família, nas paredes da nossa casa [...]" (Nassar, 1997, p. 54). Atribuindo-se o lugar daquele que detém o conhecimento necessário à obtenção deste tesouro que é o tempo, o pai fala com autoridade. Para valorizar seu papel de patriarca 
ele também evoca a figura do avô, apresentado como um sábio, e emprega frases feitas, as quais transmitiriam a sabedoria reconhecida da doxa ("dar o passo mais largo que a perna”, "colocar o carro à frente dos bois", "começar a coisas pelo teto"). No entanto, este recurso à argumentação de autoridade está ligado a uma estratégia de apropriação e de modificação do discurso de outrem, tendo em vista que certas modificaçóes são feitas em relação às formas correntes das expressóes mencionadas acima: "dar o passo maior que a perna", "colocar a carroça na frente dos bois", "começar a casa pelo teto". Apesar de sutis, tais modificaçóes são significativas e assinalam ao leitor atento outras prováveis alteraçôes da doxa feitas pelo patriarca a fim de atingir seus objetivos.

A seguir, por uma preocupação didática — correspondente ao dever de docere $e^{8}$ no sermáo sobre o tempo as diretivas de comportamento e as proibições são intercaladas (Nassar, 1997, p. 54-55); as puniçóes destinadas aos que desobedeceriam a tais indicações (Nassar, 1997, p. 57) são seguidas por proibiçóes (Nassar, 1997, p. 58), às quais sucede a enumeração das vantagens que traria a obediência ao tempo (Nassar, 1997, p. 58-59), e, ao final, uma soluçáo prática é preconizada: "as dores da nossa vontade só chegarão ao santo alívio seguindo esta lei inexorável: a obediência absoluta à soberania incontestável do tempo, não se erguendo jamais o gesto neste culto raro" (Nassar, 1997, p. 59). Esta passagem - em posição estratégica na arquitetura da homilia — remete efetivamente a um outro procedimento retórico: a parábola que vem após o sermão e que póe em cena um soberano cujos caprichos são pacientemente suportados por um homem faminto.

Um outro aspecto didático do sermão paterno é a ênfase dada à oposição entre a redenção obtida graças à obediência ao tempo e a perdição acarretada pelo mundo das paixôes, pois, à medida que a primeira é valorizada, a segunda é depreciada - de um modo bastante maniqueísta, redutor e, por conseguinte, facilmente compreensível (Nassar, 1997, p. 54-58).

Este sermão, que alterna tão bem os princípios da ordem paterna e os exemplos que os ilustram, o que não se deve e o que se deve fazer, as puniçóes e as recompensas, reflete em sua organização formal o equilíbrio pregado por seu conteúdo: "fica a salvo do malogro e livre da decepção quem alcançar aquele equilíbrio, é no manejo mágico de uma balança que está guardada toda a matemática dos sábios” (Nassar, 1997, p. 55).

Além dessas estratégias relativas à organização e à disposição dos argumentos, identificamos técnicas frequentes na prédica - como a repetição e o paralelismo, que facilitam a memorizaçâo, tanto do orador quanto de seus ouvintes, ao apresentarem os raciocínios ordenadamente ${ }^{9}$. Chegamos, portanto, à questão da elocução, ou seja, do estilo. 
Seguindo esta lógica, a anáfora dá um impulso rítmico ao enunciado:

e nenhum entre nós há de transgredir esta divisa, nenhum entre nós há de estender sobre ela sequer a vista, nenhum entre nós há de cair jamais na fervura desta caldeira insana (Nassar, 1997, p. 56-57).

ai daquele que brinca com fogo [...]; ai daquele que se deixa arrastar pelo calor de tanta chama [...]; ai daquele que deita as costas nas achas desta lenha escusa [...]; ai daquele que cair e nessa queda se largar [...]; ai daquele que queima a garganta com tanto grito [...]; ai daquele que se antecipa no processo das mudanças [...]; ai daquele, mais lascivo, que tudo quer ver e sentir de um modo intenso (Nassar, 1997, p. 57).

mas ninguém no seu entendimento há de achar que devamos sempre cruzar os braços [...], ninguém em nossa casa há de cruzar os braços quando existe a terra para lavrar, ninguém em nossa casa há de cruzar os braços quando existe a parede para erguer, ninguém ainda em nossa casa há de cruzar os braços quando existe o irmão para socorrer (Nassar, 1997, p. 58).

Outras técnicas que reforçam o caráter encantatório das anáforas entram em jogo, como a amplificação progressiva ou a acumulação. Aliás, frequentemente mais de um procedimento é utilizado, como no fragmento seguinte, em que a anadiplose - a retomada em posição inicial de uma palavra ou grupo sintático que, no segmento precedente, se situa em posição final — é concomitante à anáfora:

ninguém em nossa casa há de dar nunca o passo mais largo que a perna: dar o passo mais largo que a perna é o mesmo que suprimir o tempo necessário à nossa iniciativa; e ninguém em nossa casa há de colocar nunca o carro à frente dos bois: colocar o carro à frente dos bois é o mesmo que retirar a quantidade de tempo que um empreendimento exige; e ninguém ainda em nossa casa há de começar nunca as coisas pelo teto: começar as coisas pelo teto é o mesmo que eliminar o tempo que se levaria para erguer os alicerces e as paredes de uma casa (Nassar, 1997, p. 55).

Enquanto orador eficaz, a personagem do pai utiliza-se da razão, selecionando e organizando seus argumentos, adaptando-os em função de seu público. Ele também serve-se de seu corpo, a fim de influenciar os que o escutam através da visão e da audição. Os gestos e atitudes que corroboram a eficácia dos recursos verbais correspondem à ação oratória. Essa qualidade atua não no aspecto racional, mas no aspecto afetivo da retórica, explicitando o caráter pragmático na relação entre o locutor e o ouvinte. Em Lavoura arcaica, o personagem-narrador aprecia e destaca o desempenho de seu pai ao final do sermáo sobre o tempo: "E o pai à cabeceira fez a pausa de costume, 
curta, densa, para que medíssemos em silêncio a majestade rústica da sua postura [...] e as mãos de dorso largo prendendo firmes a quina da mesa como se prendessem a barra de um púlpito [...] o pai, ao ler, não perdia nunca a solenidade" (Nassar, 1997, p. 62-63).

Se, no romance que analisamos, a personagem do pai revela-se um mestre da palavra, tal é igualmente o caso de dois de seus filhos: Pedro, o primogênito, e André, o personagem-narrador.

De pai para filho: Pedro, o primogênito

Pedro, apresentado como discípulo de seu pai, exercita-se imitando-o. Analisaremos a seguir o domínio das estratégias retóricas que ele demonstra nos capítulos 1, 3, 5, 7, 11 e 19, a partir dos quais podemos estabelecer, ao menos parcialmente, uma linha diegética que corresponde ao diálogo entre Pedro e André no quarto de pensão.

Já que o personagem-narrador deixou a fazenda da família após haver consumado o incesto com sua irmá, o primogênito é incumbido de ir ao seu encontro e convencê-lo a voltar para casa ("ele cumpria a sublime missão de devolver o filho tresmalhado ao seio da família” - Nassar, 1997, p. 8).

Enquanto orador experiente, Pedro emprega argumentos relacionados aos sentimentos (os vínculos familiares), mas também à razão (os preceitos paternos, sustentáculo da ordem e da união da família). Uma leitura minuciosa permite-nos identificar o fio do discurso de Pedro, disperso nas falas e digressóes do personagem-narrador. Assim, quando eles se encontram, Pedro repete a seu irmão, com lágrimas nos olhos: "Nós te amamos muito", antes de tomá-lo em seus braços (capítulo 1). A seguir, ele adota um tom calmo e sereno e começa a falar sobre a família, para torná-la presente (capítulo 3). Depois, ele desenvolve os preceitos paternos, lembra o que é permitido e o que é proibido, que um indivíduo não deve ameaçar a união da família — ao mesmo tempo em que critica nas entrelinhas os desvios de seu irmão. Ele insiste no fato de que a fuga de André abalou a família e descreve a reação deles quando souberam que André havia partido (primeiro a da mãe, depois a do pai, e finalmente a dos irmãos e irmãs - capítulo 5). A fim de enternecer seu irmão, Pedro insiste no quanto a mãe deles conta com o retorno de André e a que ponto sua ausência a desestabiliza. Pedro sublinha, por fim, o mutismo no qual Ana se refugiou e o quanto ela preocupa a todos (capítulo 7).

A menção a Ana desencadeia em André uma crise na qual álcool e epilepsia levam a uma extraordinária violência discursiva. Ao longo dos capítulos 11 e 19, o personagem-narrador, em um acesso de fúria ("sanha de possesso", Nassar, 1997, p. 
110), confessa o quanto conhece dos desejos ocultos da família, suas aventuras com prostitutas e seu amor incestuoso por Ana. Embora ele não ceda a palavra a Pedro, propóe ao leitor a análise das atitudes de seu irmão mais velho, reveladoras de suas reaçôes e intençốes.

Na verdade, desde o início do romance o personagem-narrador decifra a maneira como Pedro póe em prática a variedade de tons necessária à eficácia de seu discurso:

a voz de meu irmão, calma e serena como convinha (Nassar, 1997, p. 18).

meu irmão pôs um sopro quente na sua prece pra me lembrar que havia mais força no perdão do que na ofensa e mais força no reparo que no erro (Nassar, 1997, p. 24).

ele disse misturando na sua reprimenda um certo e cada vez mais tenso sentimento de ternura, ele que vinha caminhando sereno e seguro, um tanto solene (como meu pai) (Nassar, 1997, p. 25).

ele disse grave, resoluto, estranhamente mudado [...] desistindo na certa de quebrar com seu afeto o meu silêncio [...] disse impiedoso, francamente hostil (Nassar, 1997, p. 40).

Ele também descreve os gestos cuidadosamente compostos por seu irmão, os quais chegam a substituir-se à palavra:

Tinha a ternura mais limpa do mundo no seu jeito de me olhar (Nassar, 1997, p. 38).

pude notar o cuidado que ele punha em compor um olhar e uma postura que me exortassem a continuar (Nassar, 1997, p. 47).

sua mäo ensaiando com aspereza o gesto de reprimenda, mas logo se retraindo calada e pressurosa $^{10}$ (NASSAR, 1997, p. 48).

nem ele disse qualquer coisa, logo recolhendo o aceno vago do seu gesto (Nassar, 1997, p. 70).

vendo a súbita mudança que eu provocava em meu irmáo, um impeto ruivo faiscou nos seus olhos, sua mão desenhou garranchos no ar, assustadores, essa mesma mão que já ensaiava com segurança a sucessão da mão do pai, mas tudo se apagou num instante (Nassar, 1997, p. 75).

vi que meu irmão, assombrado [...] cobria o rosto com as mãos [...] estava claro que ele tateava à procura de um bordão [...] a postura profundamente súbita e quieta (era meu pai) [...] era talvez num exercício de paciência que ele se recolbia (Nassar, 1997, p. 110-111).

O personagem-narrador de Lavoura arcaica, ao perceber e analisar o uso que seu irmão mais velho faz da ação oratória e das estratégias de argumentação, revela-se um 
hermeneuta versado no assunto, capaz de identificar as técnicas de seu irmão primogênito e, consequentemente, de subtrair-se à sua influência. Veremos a seguir como André também sobressai-se na arte da manipulação pelo discurso e da distorção do discurso de outrem.

\section{De pai para filho: André, o personagem-narrador}

Durante o diálogo inicial no quarto de pensão, André, comprovando ser um sofista experiente, adverte Pedro sobre a possibilidade e o perigo de manipulação da palavra paterna, fundamento da ordem familiar, que poderia ser inserida e utilizada em outro contexto:

era ele Pedro, era o pai que dizia sempre [...] era ele sempre dizendo coisas assim, eram pesados aqueles sermóes de família, mas era assim que ele os começava sempre, era essa a sua palavra angular, era essa a pedra em que tropeçávamos quando crianças, essa a pedra que nos esfolava a cada instante [...] mas era ele também, era ele que dizia provavelmente sem saber o que estava dizendo e sem saber com certeza o uso que um de nós poderia fazer um dia [...] era esse lavrador fibroso catando da terra a pedra amorfa que ele náo sabia tão modelável nas mãos de cada um (Nassar, 1997, p. 43-44).

Ora, esta distorção do discurso do pai é praticada pelo personagem-narrador ao longo do romance. Todavia, privilegiaremos no âmbito deste artigo duas passagens, que consideramos das mais expressivas quanto às estratégias retóricas: o diálogo/monólogo na capela, quando André se dirige a sua irmã Ana após o incesto (Nassar, 1997, p. 118142), e o confronto direto entre André e seu pai, quando do retorno daquele à fazenda (Nassar, 1997, p. 158-174).

No que tange ao episódio da capela, constatamos que, quando começa a falar, o personagem-narrador anuncia seu método e seus objetivos:

eu disse forjando alguma calma, eu tinha de provar minha paciência, falar-lhe com a razão, usar sua versatilidade, era preciso ali também aliciar os barros santos [...] fazer como tentei na casa velha, aliciar e trazer para o meu lado toda a capela (Nassar, 1997, p. 119-120).

Nesse trecho, identificamos em primeiro lugar a expressão "forjando alguma calma”, que evoca a indiferença aparente do locutor, a qual constitui um recuo necessário à eficácia da argumentação. Depois, temos a manipulação da razão pela palavra, que explora a versatilidade na apresentação das ideias — o que nos remete às afirmaçóes de 
Raduan Nassar sobre a argumentação sofística evocadas na primeira parte deste artigo. Finalmente, observamos que no intuito de seduzir Ana ("aliciar os barros santos", "aliciar a capela”) André pretende apropriar-se dos preceitos paternos ("provar minha paciência”), nos quais ela tenta refugiar-se. Tal discurso, que quer fascinar o ouvinte, funciona como uma armadilha, da qual André já possui certa experiência — "como tentei na casa velha".

Mais adiante, ele deturpa sutilmente três das proibiçóes do sermão sobre o tempo, utilizadas por seu pai para preconizar a conduta a ser seguida pela família:"ninguém em nossa casa há de cruzar os braços quando existe a terra para lavrar, ninguém em nossa casa há de cruzar os braços quando existe a parede para erguer, ninguém ainda em nossa casa há de cruzar os braços quando existe o irmão para socorrer" (Nassar, 1997, p. 58). Em seu monólogo, encontramos os dois primeiros preceitos ("terra para lavrar", "parede para erguer") nas tarefas que promete executar junto à família caso Ana aceite seu amor - "vou madrugar com nossos irmãos, seguir o pai para o trabalho, arar a terra e semear" (Nassar, 1997, p. 120-121), "vou me encarregar das ferramentas do pai [...] e cuidarei também das nossas construções" (Nassar, 1997, p. 123-124). Finalmente, ele exorta sua irmã a socorrê-lo, quer dizer, a colocar em prática o terceiro preceito em questão (“irmão para socorrer"). Este dever de auxílio mútuo, imposto aos membros da família, é explicitado no sermão sobre o tempo, não somente no trecho já citado, mas ainda pouco antes do final:

mão alguma em nossa casa há de fechar-se em punho contra o irmão acometido: os olhos de cada um, mais doces do que alguma vez já foram, serão para o irmão exasperado, e a mão benigna de cada um será para este irmáo que necessita dela, e o olfato de cada um será para respirar, deste irmão, seu cheiro virulento, e a brandura do coração de cada um, para ungir sua ferida, e os lábios para beijar ternamente seus cabelos transtornados, que o amor na família é a suprema forma de paciência (Nassar, 1997, p. 61).

Jogando com a ambiguidade entre amor fraterno/amor carnal, André distorce os argumentos paternos e não hesita em designar o incesto como uma maneira de assegurar a união da família, uma das pedras angulares da ordem paterna:

foi um milagre, querida irmá, descobrirmos [...] que vamos com a nossa união continuar a infância comum (Nassar, 1997, p. 120).

foi um milagre descobrirmos acima de tudo que nos bastamos dentro dos limites da nossa própria casa, confirmando a palavra do pai de que a felicidade só pode ser encontrada no seio da família (Nassar, 1997, p. 120). 
não permita que eu reste à margem (Nassar, 1997, p. 125).

quero fazer parte e estar com todos (Nassar, 1997, p. 125; 126).

me ajude a me perder no amor da família com o teu amor, querida irmã (Nassar, 1997, p. 128-129).

Se André conhece bem as ideias do pai, que utiliza para atingir seus próprios fins, ele também conhece certos recursos recorrentes da retórica paterna, de que lança mão para confundir Ana. Mais do que o pai em seu sermão, ele acentua a acumulação de exemplos e de argumentos decisivos para ser convincente. É certamente a este caráter repetitivo e sistemático que o narrador se refere quando salienta sua própria "insistência obsessiva” (Nassar, 1997, p. 130). Certas passagens de seu monólogo constituem verdadeiras litanias através das quais o personagem-narrador constrói um discurso encantatório. Dentre tantas outras técnicas empregadas, identificamos uma rede de repetiçóes que se estabelece segundo duas modalidades.

A primeira modalidade concentra ocorrências repetitivas em um espaço textual reduzido. Assim, por exemplo, encontramos três ocorrências encadeadas - "te amo, Ana" "te amo, Ana" "te amo, Ana" (Nassar, 1997, p. 119) — ou ainda sete ocorrências mais afastadas, ainda que na mesma página - "foi um milagre" (Nassar, 1997, p. 120). Citemos igualmente as três ocorrências de "que culpa temos nós" (Nassar, 1997, p. 130), associadas às seis ocorrências de "não tenho culpa" (Nassar, 1997, p. 137), cujo caráter expiatório é flagrante.

Numa longa sequência de três páginas (Nassar, 1997, p. 121-123), o personagemnarrador retoma treze vezes a primeira pessoa do singular do verbo "saber" no presente do indicativo para evocar o mais exaustivamente possível as numerosas tarefas que ele efetuaria na fazenda. Para reforçar o efeito desta acumulação de exemplos, a ideia principal é claramente sintetizada um pouco mais adiante: "Sou versátil, querida irmã, me presto para qualquer serviço, quero fazer coisas, tenho os braços esperando, quero ser chamado no que for preciso, não me contenho de tanta energia, não há tarefa na fazenda que não possa me ocupar à luz do dia” (Nassar, 1997, p. 124).

Segue-se uma outra sequência de duas páginas (Nassar, 1997, p. 127-128) na qual reaparecem construçóes paralelas introduzidas pelo uso de verbos conjugados na primeira pessoa do singular do futuro imediato ("vou estar bem com cada irmão", "vou falar sobre coisas simples como todos falam", "vou tomar-lhe de empréstimo um verbo túrgido" "vou cumprimentar aqueles com quem cruzo", "vou dar um dedo de prosa em cada venda", "vou caminhar na sua direção", "vou assombrá-lo”, "vou pressentir no seu rosto o júbilo mal contido", "vou sentir na testa a carne áspera do seu beijo austero"). 
A essa série, introduzida por "tudo vai mudar" (Nassar, 1997, p. 127), corresponde uma série de outras cinco ocorrências do futuro imediato (Nassar, 1997, p. 120-124), introduzida por sua vez por "as coisas vão mudar daqui pra frente" (Nassar, 1997, p. 120). Evidentemente, a utilização que André faz desse tempo verbal (associada à do futuro simples) opera no sentido de construir uma descrição convincente do que seria a vida deles junto à família, deixando pouco espaço para eventuais hesitaçóes por parte de sua irmã: "deste teu gesto dependem minhas atitudes, minha conduta, minhas virtudes" (Nassar, 1997, p. 130).

A segunda modalidade em que se estrutura a rede de repetiçôes que identificamos é baseada em retomadas dispersas ao longo da primeira metade do monólogo de André na capela - como por exemplo a fórmula "Ana, me escute, é só o que te peço" (Nassar, 1997, p. 119, 126) ou ainda as doze ocorrências de "querida irmä" (Nassar, 1997, p. $120 ; 122 ; 125 ; 126 ; 127 ; 129 ; 130 ; 131)^{11}$. Aliás, quando o personagem-narrador percebe que sua argumentação fundamentada nas promessas de uma integração harmoniosa de seu amor incestuoso à família não atinge o efeito desejado, a expressão "querida irmâ" transforma-se em "querida Ana” (Nassar, 1997, p. 133, 134, 136).

\section{Entre o pai e o filho: o combate verbal}

A estratégia retórica que consiste em distorcer o discurso de outrem também é empregada no único diálogo direto do romance, que se dá entre André e o patriarca, na noite em que retorna à fazenda (Nassar, 1997, p. 158-174). Neste combate verbal, é ora o pai, ora o filho, que retoma um elemento do discurso do outro para deformálo e integrá-lo à sua própria argumentação. Assim, bem no início do capítulo 25 , identificamos, dentre tantas outras, as seguintes réplicas:

- Meu coração está apertado de ver tantas marcas no teu rosto, meu filho; essa é a colheita de quem abandona a casa por uma vida pródiga.

- A prodigalidade também existia em nossa mesa

- Nossa mesa é comedida, e austera [...]

- Mas comemos sempre com apetite.

- O apetite é permitido [...] desde que seja moderado (Nassar, 1997, p. 158159).

— [...] não há espera sem recompensa, quantas vezes eu não contei para vocês a história do faminto?

— Eu também tenho uma história, pai, é também a história de um faminto [...] sobrevivendo à custa de tantas chagas, ele só podia odiar o mundo. 
— [...] Nada te faltava. [...] ponha de lado essas histórias de famintos, que nenhuma delas agora vem a propósito (Nassar, 1997, p. 159-160).

- [...] Para que as pessoas se entendam, é preciso que ponham ordem em suas idéias $[\ldots]$.

- Toda ordem traz uma semente de desordem (Nassar, 1997, p. 160).

- [...] uns poucos dias de trabalho ao lado de teus irmáos hão de quebrar o orgulho da tua palavra, te devolvendo depressa a saúde de que você precisa.

- Por ora, náo me interesso pela saúde de que o senhor fala (Nassar, 1997, p. 161-162).

A primeira parte do diálogo, na qual as réplicas das duas personagens têm aproximadamente a mesma extensão (Nassar, 1997, p. 158-163), é seguida por um fragmento no qual as réplicas do filho são mais longas, pontuadas pela perplexidade do pai (Nassar, 1997, p. 163-165):

- Não quero acreditar no pouco que te entendo, meu filho (Nassar, 1997, p. 163).

- É muito estranho o que eu estou ouvindo (Nassar, 1997, p. 164).

- Não vejo como todas essas coisas se relacionam, vejo menos ainda por que te preocupam tanto. Que é que você quer dizer com tudo isso? (Nassar, 1997, p. 165).

- Quero te entender, meu filho, mas já năo entendo nada (Nassar, 1997, p. 165).

Finalmente, eles exprimem-se um após o outro, mais longamente (Nassar, 1997, p. 166-168). André recusa-se a renunciar a suas ideias, rejeitando a assimilação que decorreria de tal atitude: "Não acredito na discussão dos meus problemas, não acredito mais em troca de pontos de vista" (Nassar, 1997, p. 162). À relativização que seu filho quer introduzir na "troca" de ideias — "A realidade não é a mesma para todos [...] É um ponto de vista" (Nassar, 1997, p. 166) - o pai opóe a afirmação de sua lei hegemônica, veiculadora de uma verdade que se quer irrefutável - "Corrija a displicência dos teus modos de ver [...] Não é um ponto de vista!” (Nassar, 1997, p. 166-167). E a discussão acaba em uma longa réplica na qual André aparentemente cede à vontade do patriarca pronunciando as palavras de submissão que este esperava: "Estou cansado, pai, me perdoe. [...] quero merecer de coração sincero, pai, todo o teu amor" (Nassar 1997, p. 170). Contudo, trata-se indubitavelmente de um recuo tático, como confirma o comentário do personagem-narrador: "o meu suposto recuo na discussáo com o pai" (Nassar, 1997, p 171). 


\section{Conclusão}

Por seu comportamento, mas também por seu discurso, o personagem-narrador de Lavoura arcaica traz à tona os desejos ocultos da família aparentemente pura, evidenciando a parte de trevas que há na luz e a parte de ilusório de que a realidade é feita. Com efeito, quando tenta instituir um espaço para a diferença ("Admito que se pense o contrário" - LA, p. 162) e, destarte, legitimar a multiplicidade de pontos de vista, ele introduz em uma ordem familiar esclerosada e rígida a distinção entre o verdadeiro e o verossímil. Tal demarcação encontra-se na base da retórica, como o sublinham Michèle Aquien e Georges Molinié em seu Dictionnaire de rhétorique et poétique:

A verossimilhança [...] é por excelência o domínio do retórico. É, finalmente, um conceito ao mesmo tempo lógico, ético, social e estético. [...] A verossimilhança corresponde também a uma construçáo ou a um sentimento intelectual das relaçôes do homem e do mundo. É o meio da persuasão, na medida em que esta intenção verbal implica um consenso espiritual sobre os principais parâmetros da vida em sociedade, cuja grande referência é a verossimilhança (Aquien e Molinié, 1996, entrada "vraisemblable").

Consequentemente, é a questão fundamental da verdade que a análise da retórica na obra de Raduan Nassar evidencia, já que enquanto "sofista-trapaceiro" o personagem-narrador destaca a ambiguidade inerente a todo discurso. Se ele aparece como um provável vetor de mudança - na medida em que póe abaixo o edifício dos valores paternos, baseado em uma visão do mundo que se pretende imutável - é na verdade para denunciar que uma nova ordem seria igualmente ilusória, uma verossimilhança a mais a serviço de um novo detentor do poder.

Longe dos estereótipos do que alguns consideram ser a "literatura engajada", Lavoura arcaica trata do questionamento tanto das relaçóes de força quanto de uma ordem imposta, que pode ser desmascarada graças ao deciframento das técnicas utilizadas pelo orador. $\mathrm{Na}$ medida em que esta seria uma das chaves para a exegese do romance de Raduan Nassar, é legítimo que nos interroguemos sobre os meios de que se serve o escritor e jornalista para estruturar as tentativas de manipulaçáo entre suas personagens. Se o leitor aceitar a proposta e implicar-se em identificar tais estratégias, ele certamente conseguirá evitar as eventuais armadilhas que elas podem criar, seja neste romance ou em outros textos e discursos. E tal incitação à reflexão própria permanece atual, trinta anos após a primeira edição de Lavoura arcaica.

\section{$\operatorname{son} 2$}




\section{NOTAS}

1 Uma primeira versão deste trabalho foi apresentada com o título de "Les tricheries d'un sophiste" no âmbito do primeiro Congresso du Groupement d'Intérêt Scientifique (GIS) Amérique latine, dedicado à temática "Discours et pratiques de pouvoir en Amérique latine, de la période pré-colombienne à nos jours", 03-04/11/2005, na Universidade de La Rochelle.

2 Em artigos precedentes, pudemos demonstrar, por um lado, que, contrariamente ao que se repetiu durante muito tempo, Lavoura arcaica não é uma versão conformista da parábola bíblica do filho pródigo e, por outro lado, que esse romance faz parte de uma tríade também formada pela parábola em questão e por Le retour de l'enfant prodigue, de André Gide — sendo que o texto de Nassar apresenta um filho pródigo ainda mais insubmisso que o do texto do escritor francês (Wrege Rassier, 2003). Também demonstramos como o substrato de ideias de René Descartes e de Francis Bacon - referências teóricas veladas e codificadas em entrevistas dadas por Nassar - incitam, em seus textos ficcionais, tanto ao questionamento das autoridades e de seus dogmas quanto à formação do indivíduo como ser autônomo e emancipado (Wrege Rassier, 2004).

3 Tendo nascido em novembro de 1935, Raduan Nassar tinha dezenove anos quando iniciou seus estudos universitários em Direito e Letras Clássicas, em 1955. Foi provavelmente nessa época que ele descobriu os sofistas. Todavia, ele teve certamente a oportunidade de aprofundar suas leituras sobre esse assunto entre 1957 e 1963, quando assistiu aos cursos de Filosofia na Universidade de São Paulo (USP).

4 "Na minha adolescência, andei em más companhias, trapaceiros e caloteiros, mas de que trago boas lembranças por terem sugerido posturas para a reflexão" (Cadernos de Literatura Brasileira, 1996, p. 39).

5 "Veja bem - nos meus dezenove anos [...] esbarrei [...] nos sofistas, aqueles trapaceiros da Antiguidade, que se encarregaram na época de desmoralizar o uso da razão"; "Afinal, eu também pensava, como os sofistas, que a razão não era exatamente aquela donzela cheia de frescor que acaba de sair de um banho numa tarde de verão. Ao contrário, era uma dama experiente que não resistia a uma única cantada, viesse de onde viesse, concedendo inclusive os seus favores a quem pretendesse cometer um crime. O aporte ético, que tentaram colar nela desde os tempos antigos, lhe é totalmente estranho"(Cadernos de Literatura Brasileira, 1996, p. 37-38).

6 "A invenção consiste em encontrar os argumentos verdadeiros ou verossímeis próprios para tornar a causa convincente. A disposição ordena e reparte os argumentos: ela mostra o lugar que deve ser atribuído a cada um deles. O estilo adapta palavras e frases apropriadas ao que a invenção fornece. A memória consiste em lembrar adequadamente as idéias, as palavras e sua disposição. A ação oratória consiste em disciplinar e tornar agradáveis a voz, as nuances da fisionomia e os gestos" (Rhétorique à Herennius, I, 3 - traduçáo nossa).

7 No que tange às palavras em itálico nas citaçôes de Lavoura arcaica, o grifo é nosso.

$8 \mathrm{Na}$ retórica clássica, os três deveres do orador são: docere (ensinar), movere (emocionar) e delectare (agradar)

9 Contudo, convém lembrar que, após seu sermão, o pai abre uma "velha brochura" na qual conserva os textos que compila (Nassar, 1997, p. 63) e entáo começa não a recitar, mas a ler a parábola do faminto.

10 A retórica clássica codificou o recurso aos gestos da mão sob a apelação de quironomia. Quintiliano, por exemplo, exprime-se sobre a "loquacidade" das mãos nos seguintes termos "As outras partes do 
corpo certamente ajudam a quem fala, mas quanto às mãos, quase ouso dizer que elas falam por si mesmas" (Quintiliano, Institution oratoire, XI, 3, 85 - tradução nossa).

11 Três destas ocorrências são por sua vez imediatamente associadas à expressão "foi um milagre", o que amplifica o efeito da "insistência obsessiva" do personagem-narrador.

\section{REFERÊNCIAS}

AQUIEN, Michèle e MOLINIÉ, Georges. Dictionnaire de rhétorique et poétique. Paris: Le Livre de Poche, col.: Encyclopédies d'aujourd'hui, 1996.

ARISTÓTELES. Réfutations sophistiques. Trad., introdução e comentários de Louis-André Dorion, Paris: Vrin; Québec: Presses de l'Université de Laval, col. "Histoire des doctrines de l'Antiquité classique", 1995.

BONASSA, Elvis César. Raduan crê na literatura só como questão pessoal — você pode falar uma coisa e seu contrário. Folha de S. Paulo, São Paulo, 30/05/1995.

CADERNOS DE LITERATURA BRASILEIRA: RADUAN NASSAR. São Paulo: Instituto Moreira Salles, n.2, set. 1996.

DUMONT, Jean-Paul, DELATTRE, Daniel e POIRIER, Jean-Louis (org.). Les présocratiques. Paris: Gallimard, col. Bibliothèque de la Pléiade, 1988.

MASSI, Augusto e SABINO FILHO, Mário. A paixão pela literatura. Folha de S. Paulo, São Paulo, $16 / 12 / 1984$.

NASSAR, Raduan. Lavoura arcaica. São Paulo: Companhia das Letras, 1997.

PERRONE-MOISÉS, Leyla. Raduan Nassar: Lavoura arcaica. Colóquio Letras, Fundação Calouste Gulbenkian, Lisboa, n. 38, p. 96-97 jul. 1977.

PLATÃO. O sofista. In: ___ Diálogos. Trad. e notas de Jorge Paleikat e João Cruz Costa, São Paulo: Nova Cultural, col. "Os pensadores", 1987.

QUINTILIANO. Institution oratoire. Trad. Jean Cousin, Paris: Les Belles Lettres, col. Des universités de France, 1979, livres XI e XII.

RHÉTORIQUE À HERENNIUS. Trad. Guy Achard, Paris: Les Belles Lettres, col. Des universités de France, 1989.

WREGE RASSIER, Luciana. Trois enfants prodigues: une étude de l'intertextualité dans Lavoura arcaica, de Raduan Nassar, in DUMAS, Marie e UTEZA, Francis (Org.), Mélanges offerts à Claude Maffre. Montpellier: Université Paul-Valéry, col.: ETILAL — Études Ibériques, Latino-Américaines et Lusophones, 2003, p. 271-287.

WREGE RASSIER, Luciana. De la solidité précaire de l'ordre selon Raduan Nassar, in OLIVIERI-GODET, Rita e HOSSNE, Andrea (Org.), La littérature brésilienne de 1970 à nos jours. Rennes: Presses Universitaires de Rennes, 2007, p. 77-92. 


\section{Resumo}

O escritor e jornalista paulista Raduan Nassar publica Lavoura arcaica em 1975, durante a ditadura militar. Esse romance, frequentemente descrito como uma versão da parábola bíblica do filho pródigo, póe em cena o universo de uma família organizada em torno da ordem paterna, de valores austeros baseados no trabalho e na disciplina. Longe dos estereótipos de uma suposta "literatura engajada", Lavoura arcaica trata do questionamento tanto das relaçóes de força quanto de uma ordem imposta, que pode ser desmascarada graças ao estudo das técnicas retóricas utilizadas pelas personagens. Com efeito, se o leitor implicar-se em identificar as estratégias de manipulação através da arte oratória, ele conseguirá evitar as eventuais armadilhas que elas podem criar, seja nesse romance ou em outros textos e discursos. Tal incitação à reflexão própria e à insubmissão a uma ordem arbitrária permanece atual, trinta anos após a primeira edição de Lavoura arcaica.

Palavras-chave: Literatura brasileira, Literatura e poder, Literatura e retórica, Problemática identitária.

\section{Résumé}

L'écrivain et journaliste brésilien Raduan Nassar publie Lavoura arcaica, en 1975, lorsque le Brésil est gouverné par la dictature militaire. Ce roman, souvent décrit comme une version de la parabole biblique de l'enfant prodigue, met en scène l'univers d'une famille organisée autour de l'ordre paternel aux valeurs austères basées sur le travail et la discipline. Loin des stéréotypes d'une supposée "littérature engagée" Lavoura arcaica porte sur la mise en question des rapports de force et d'un ordre imposé, qui est démasqué grâce à l'étude des techniques rhétoriques utilisées par les personnages. En effet, si le lecteur accepte le pari et s'emploie à identifier les stratégies de la manipulation par le discours il parviendra sans doute à mieux déjouer leurs pièges éventuels, que ce soit dans ce roman ou ailleurs. Par conséquent, cette incitation à la réflexion propre et à l'insoumission à un ordre arbitraire reste d'actualité, trente ans après la parution de Lavoura arcaica.

Mots-clés: Littératurebrésilienne; Littérature etpouvoir; Littérature et rhétorique; Problématique identitaire.

Luciana Wrege Rassier é graduada em Letras pela Universidade Federal de Pelotas (1992); mestrado em Diplôme d'Etudes Approfondies em línguas românicas, estudos luso-brasileiros - Université Montpellier III (1995), e doutorado em Línguas Românicas — Université Montpellier III, em regime de co-tutela com a UFRGS (2002). Lecionou em algumas universidades francesas (1994 a 2010). Atualmente, é docente-pesquisadora na Universidade Federal de Santa Catarina. 